\title{
Modelling maize grain yield and nitrate leaching from sludge-amended soils across agro-ecological zones: A case study from South Africa
}

\author{
ZM Ogbazghi', EH Tesfamariam* and JG Annandale \\ 'Department of Plant and Soil Sciences, University of Pretoria, Private Bag:X20, Hatfield, 0028, Pretoria, South Africa
}

\begin{abstract}
When applying municipal sludge according to crop $\mathrm{N}$ requirements, the primary aim should be optimizing sludge application rates in order to maximize crop yield and minimize environmental impacts through nitrate leaching. Nitrate leaching and subsequent groundwater contamination is potentially one of the most important factors limiting the long-term viability of sludge application to agricultural soils. This study assessed maize grain yield and potential nitrate leaching from sludge-amended soils, using the SWB-Sci model, based on crop nitrogen requirements and inorganic fertilizer. The following hypotheses were tested using the SWB-Sci model and 20 years of measured weather data for 4 of the 6 South African agro-ecological zones. Under dryland maize cropping, grain yield and nitrate leaching from sludge-amended soils compared to inorganic fertilizer: (1) will remain the same across agro-ecological zones and sites, (2) will not vary across seasons at a specific site, and (3) will not vary across soil textures. Model simulations showed that annual maize grain yield and nitrate leaching varied significantly $(P>0.05)$ across the four agro-ecological zones, both for sludge-amended and inorganic fertilizer amended soils. The annual maize grain yield and nitrate leaching from sludge-amended soils were $12.6 \mathrm{t} \cdot \mathrm{ha}^{-1}$ and $32.7 \mathrm{kgNO}_{3}-\mathrm{N} \cdot \mathrm{ha}^{-1}$ compared to $10.2 \mathrm{t} \cdot \mathrm{ha} \mathrm{a}^{-1}$ and $43.2 \mathrm{kgNO}_{3}-\mathrm{N} \cdot \mathrm{ha}^{-1}$ for inorganic fertilizer in the super-humid zone. Similarly, maize grain yield and nitrate leaching varied significantly across seasons and soil textures for both sludge and inorganic fertilizer amended soils. However, nitrate losses were lower from sludge-amended soils (2.3-8.2\%) compared to inorganic fertilizer (11.1-26.7\%) across all zones in South Africa. Therefore, sludge applied according to crop $\mathrm{N}$ requirements has a lower environmental impact from nitrate leaching than commercial inorganic fertilizer. Further validation of these findings is recommended, using field studies, and monitoring potential $\mathrm{P}$ accumulation for soils that received sludge according to crop $\mathrm{N}$ requirements.
\end{abstract}

Keywords: sewage sludge, inorganic fertilizer, nitrate leaching, maize yield, agro-ecological zones, SWB-Sci

\section{INTRODUCTION}

Generally, biosolids are applied to agricultural lands based on the N requirement of crops (USEPA, 2012; AlvarezCampos, 2019). This is a common practice, especially on soils with high P-fixing abilities. When applying sludge according to crop $\mathrm{N}$ requirements, the primary aim should be optimizing sludge application rates in order to maximize crop yield and minimize environmental impacts through nitrate leaching. Unlike inorganic fertilizer, a large fraction of the $\mathrm{N}$ from sludge is in organic form and is gradually

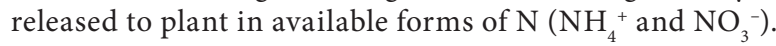
Consequently, nitrate leaching from sludge-amended agricultural lands is expected to be minimal compared to soils which receive similar amounts of inorganic fertilizer (Tesfamariam et al., 2015).

Previous studies by Tesfamariam (2009) and Kayikcioglu and Delibacak (2018) have shown that there is a linear relationship between sludge application rate and maize, oat, and weeping lovegrass yield, until a point of diminishing return, which is often linked to the availability of water. This direct relationship was mainly due to an increase in plant-available $\mathrm{N}$ from sludge, which is considered the key element for dry matter production (Miles and Manson, 2000). An increase in sludge application rate may, however, lead to excessive nitrate leaching, especially when the rate of $\mathrm{N}$ release exceeds crop uptake (Tesfamariam et al., 2015; Paramashivam et al., 2017).

According to Ogbazghi et al. (2016), $\mathrm{NO}_{3}-\mathrm{N}$ leaching and subsequent groundwater contamination is a potential

*Corresponding author, email: eyob.tesfamariam@up.ac.za

Received 4 April 2018; accepted in revised form 20 September 2019 concern with the long-term sustainability of uncontrolled biosolid application to agricultural lands. Nitrate leaching is controlled by soil water dynamics and is a function of the nitrate concentration in soil solution (Ogbazghi et al., 2016; Zhao et al., 2019). Soil water dynamics is influenced by soil properties such as texture and structure, as well as by the availability of water through irrigation and/or rainfall. Nitrate leaching from agricultural lands is a result of a complex interaction between $\mathrm{N}$ transformation processes, soil water dynamics, and soil characteristics. Henceforth, the need for decision support tools is becoming quite important due to the ever-increasing concerns over environmental pollution associated with the use of organic and inorganic fertilizers (Tesfamariam et al., 2015). Several N computer models, as decision support tools, have been developed with varying levels of complexity depending on their purpose (Banger et al., 2017).

The SWB-Sci model is a mechanistic soil-water balance (Annandale et al., 2000), crop growth/irrigation scheduling (Annandale et al., 2000, 2003), N (Tesfamariam, 2009; Ogbazghi et al., 2016) and phosphorus (P) (Van der Laan et al., 2010) model. It has been successfully calibrated and validated for $\mathrm{N}$ dynamics in sludge-amended soils planted to maize, oats and weeping love grass, both under dryland and irrigated conditions (Tesfamariam et al., 2015).

The objective of this study was to assess maize grain yield and potential nitrate leaching using the SWB-Sci model from soils amended with sludge, based on crop N requirements adjusted for several South African agroecological zones. To achieve this, the following hypotheses were tested using the SWB-Sci model and 20 years of measured weather data for 4 of the 6 South African 
agro-ecological zones. Under dryland maize cropping, maize grain yield and nitrate leaching from sludge-amended soils compared with inorganic fertilizer: (i) will remain the same across agro-ecological zones and sites; (ii) will not vary across seasons at a specific site; and (iii) will not vary across soil textures.

\section{MATERIALS AND METHODS}

\section{Model description}

The SWB-Sci model is a mechanistic crop growth, irrigation scheduling, salt, $\mathrm{N}$ and $\mathrm{P}$ balance model. It is a generic onedimensional, daily time-step model that uses soil, weather and crop units to mechanistically carry out crop growth, soilwater and salt balances, as well as nitrogen cycle simulations. A detailed description of the crop growth, irrigation scheduling, salt, and water balance modules of the SWB-Sci model is not presented in this paper, and can be found in Annandale et al. (2000).

The Nitrogen module of the SWB-Sci model follows a similar approach to that of the Cropping Systems Simulation Model (CropSyst) (Stöckle et al., 2003). The nitrogen balance in the SWB-Sci module includes nitrogen transformations (mineralisation, nitrification, denitrification and ammonia volatilisation), ammonium sorption, nitrogen transport and crop nitrogen uptake. The model simulates ammonium sorption using the approach presented by Stöckle and Campbell (1989), while symbiotic $\mathrm{N}$ fixation is simulated after the approaches of Bouniols et al. (1991). Crop nitrogen uptake is modelled using a modified version of the Godwin and Jones (1991) approach, where crop nitrogen uptake is determined as the lesser of crop nitrogen demand and potential nitrogen uptake (Stöckle et al., 1994). A detailed description of the $\mathrm{N}$ module, including the major nitrogen transformation processes, can be found in Stöckle et al. (2003).

\section{Model parameterization}

\section{Soil}

Four major soil textural classes (clay, clay loam, sandy clay loam and sandy loam) were selected from our database to investigate maize crop yield and potential nitrate leaching from sludge-amended soils that received sludge based on crop $\mathrm{N}$ requirements adjusted for each agro-ecological zone, using inorganic fertilizer as a benchmark. Selected physical and chemical properties of the four soil textural classes used for model simulation are presented in Table 1 .

\section{Sludge}

The sludge used for simulations in this study was anaerobically digested and dried on conventional concrete beds. The sludge was digested to $33 \%$ volatile suspended solids (VSS) destruction under mesophilic conditions. The retention time was 15 days in primary and 2 days in secondary digesters. Sludge properties required for model parameterization to run scenario simulations are presented in Table 2 .

\section{Inorganic fertilizer}

The amount and timing of inorganic fertilizer application for this modelling work was based on the Fertilizer Handbook (FSSA, 2007) to meet the target yield for each selected site. The fertilizer was applied at planting and top dressed 5 weeks later according to the FSSA (2007) recommendations presented in Table 3. Limestone ammonium nitrate (LAN) with $28 \% \mathrm{~N}$ content was used as a source of nitrogen to meet the crop $\mathrm{N}$ requirement in this study.

\section{Crop}

Maize was selected as test crop because it is one of the most widely cultivated crops across the globe and accounts for $51 \%$ of the cultivated land in South Africa (FAO, 2005). A well-studied maize cultivar, PAN 6966, was selected and certain crop model parameters are presented in Table 4.

Table 2. Selected properties of the anaerobically digested sludge used for model parameterization

\begin{tabular}{lcc}
\hline Sludge parameter & Units & Value \\
\hline $\mathrm{C}$ & $\%$ & 17 \\
Total $\mathrm{N}$ & $\%$ & 2.81 \\
$\mathrm{NH}_{4}-\mathrm{N}$ & $\%$ & 0.264 \\
$\mathrm{NO}_{3}-\mathrm{N}$ & $\%$ & 0.051 \\
$\mathrm{P}$ & $\%$ & 3.02 \\
$\mathrm{pH}\left(\mathrm{H}_{2} \mathrm{O}\right)$ & $\mathrm{NA}$ & 5.86 \\
Water content & $\%$ & 30 \\
Fast cycling fraction & $\mathrm{kg} \cdot \mathrm{kg}^{-1}$ & 0.3 \\
Slow cycling fraction & $\mathrm{kg} \cdot \mathrm{kg}^{-1}$ & 0.3 \\
Fast cycling half-life & days & 3 \\
Slow cycling half-life & days & 60 \\
C: $\mathrm{N}$ ratio & $\mathrm{kg} \cdot \mathrm{kg}^{-1}$ & 8 \\
\hline
\end{tabular}

Table 1. Selected soil physical and chemical characteristics of the four soil textures used for model scenario simulations

\begin{tabular}{|c|c|c|c|c|c|}
\hline \multirow{2}{*}{ Selected characteristics } & \multirow{2}{*}{ Unit } & \multicolumn{4}{|c|}{ Soil textures } \\
\hline & & Clay & Clay loam & Sandy clay loam & Sandy loam \\
\hline Field capacity (FC) & $m \cdot m^{-1}$ & 0.479 & 0.328 & 0.255 & 0.196 \\
\hline Permanent wilting point (PWP) & $\mathrm{m} \cdot \mathrm{m}^{-1}$ & 0.131 & 0.139 & 0.096 & 0.107 \\
\hline Bulk density & $\mathrm{Mg} \cdot \mathrm{m}^{-3}$ & 1.207 & 1.314 & 1.401 & 1.557 \\
\hline Sand & $\%$ & 20 & 32 & 60 & 65 \\
\hline Clay & $\%$ & 60 & 34 & 27 & 10 \\
\hline Organic matter & $\%$ & 2.8 & 2.5 & 1.6 & 1.5 \\
\hline$\Psi_{\mathrm{FC}}$ & $\mathrm{kPa}$ & -30 & -30 & -30 & -30 \\
\hline$\Psi_{\mathrm{PWP}}$ & $\mathrm{kPa}$ & -1500 & -1500 & -1500 & -1500 \\
\hline Drain factor & - & 0.3 & 0.5 & 0.8 & 0.9 \\
\hline Root depth limit & M & 2 & 2 & 2 & 2 \\
\hline
\end{tabular}


Table 3. Inorganic fertilizer application timing and amounts used for scenario simulation across selected sites in South African agro-ecological zones (FSSA, 2007)

\begin{tabular}{|c|c|c|c|c|c|}
\hline \multirow{3}{*}{$\begin{array}{l}\text { Agro-ecological } \\
\text { zone }\end{array}$} & \multirow{3}{*}{$\begin{array}{l}\text { Selected } \\
\text { sites }\end{array}$} & \multicolumn{4}{|c|}{ Inorganic fertilizer (LAN) application timing and date } \\
\hline & & \multicolumn{2}{|c|}{$\begin{array}{l}\text { First split application } \\
\text { (at planting) }\end{array}$} & \multicolumn{2}{|c|}{$\begin{array}{l}\text { Second split application } \\
\text { (five weeks after planting) }\end{array}$} \\
\hline & & Date & $\begin{array}{l}\text { Amount } \\
\left(\mathrm{kg} \cdot \mathrm{ha}^{-1}\right)\end{array}$ & Date & $\begin{array}{l}\text { Amount } \\
\left(\mathrm{kg} \cdot \mathrm{ha}^{-1}\right)\end{array}$ \\
\hline \multirow[t]{3}{*}{ Semi-arid } & Bloemfontein & 27 Oct & 24 & $5 \mathrm{Dec}$ & 23 \\
\hline & Rustenburg & 27 Oct & 37 & $5 \mathrm{Dec}$ & 35 \\
\hline & Polokwane & 27 Oct & 33 & $5 \mathrm{Dec}$ & 33 \\
\hline \multirow[t]{3}{*}{ Sub-humid } & Johannesburg & $1 \mathrm{Nov}$ & 60 & $10 \mathrm{Dec}$ & 60 \\
\hline & Port Alfred & $27 \mathrm{Oct}$ & 45 & $5 \mathrm{Dec}$ & 45 \\
\hline & Bethlehem & $1 \mathrm{Nov}$ & 45 & $10 \mathrm{Nov}$ & 45 \\
\hline \multirow[t]{3}{*}{ Humid } & Durban & $1 \mathrm{Oct}$ & 75 & $7 \mathrm{Nov}$ & 75 \\
\hline & East London & $27 \mathrm{Oct}$ & 65 & $5 \mathrm{Dec}$ & 65 \\
\hline & Cape Town & $10 \mathrm{Nov}$ & 65 & $18 \mathrm{Dec}$ & 65 \\
\hline Super-humid & Nelspruit & $10 \mathrm{Oct}$ & 85 & $18 \mathrm{Nov}$ & 85 \\
\hline
\end{tabular}

Table 4. Selected properties of the maize used for model parameterization

\begin{tabular}{lcc}
\hline Crop parameter & Units & Value \\
\hline Emergence & day deg & 50 \\
Flowering & day deg & 1000 \\
Maturity & day deg & 1700 \\
Transition & day deg & 10 \\
Leaf senescence & - & 1300 \\
Maximum crop height & $\mathrm{M}$ & 3.20 \\
Maximum root depth & $\mathrm{M}$ & 1.20 \\
Minimum leaf water potential & $\mathrm{kPa}$ & -1500 \\
Maximum transpiration & $\mathrm{mm}^{\circ} \mathrm{day}^{-1}$ & 9 \\
Specific leaf area & $\mathrm{m}^{2} \cdot \mathrm{kg}^{-1}$ & 15 \\
Leaf-stem partitioning & $\mathrm{m}^{2} \cdot \mathrm{kg}^{-1}$ & 0.80 \\
Root fraction & - & 0.02 \\
Root growth rate & - & 8 \\
Grain N partition coefficient & - & 0.30 \\
Root N concentration & $\mathrm{kgN} \cdot \mathrm{kgDM}^{-1}$ & 0.01 \\
Maximum grain N concentration & $\mathrm{kgN} \cdot \mathrm{kgDM}^{-1}$ & 0.02 \\
\hline
\end{tabular}

\section{Study site}

Scenario simulations were run using the SWB-Sci model for 4 of the 6 major agro-ecological zones of South Africa (Table 5, Column 1) to predict maize grain yield and nitrate leaching from sludge-amended soils using inorganic fertilizer as price benchmark.

The potential yield of maize for the representative sites and inorganic fertilizer recommendations for each site were obtained from FSSA Guidelines (2007) and Du Plessis (2003) (Table 5). Sludge application/recommendation rate was estimated based on the annual sludge $\mathrm{N}$ release rates adjusted to match the crop $\mathrm{N}$ requirements (Table 5, Column 6) using the SWB-Sci model (Ogbazghi et al., 2015).

Long-term weather records for the selected sites within each agro-ecological zone were obtained from the South African Weather Service (SAWS) for 1993-2013. SAWS collates, maintains and runs a quality control process of South Africa's meteorological and climatological data and related information. This archived data consists of daily rainfall values since 1936 as well as mean hourly and daily data of wind direction, wind speed, temperature, humidity, pressure and sunshine since 1950. Two sites, Nelspruit and Port Alfred, were exceptions, since data were available only for 2002-2013. The annual rainfall figures (1993-2013) of the selected sites are presented in Table 6.

\section{Simulation and statistical analyses conducted}

Simulations of 80 scenarios were done based on fully factorial combinations of 4 agro-ecological zones with 3 sites for the semi-arid, sub-humid and humid zones and one for the superhumid zone, and 4 soil textures. Each scenario was run for 20 years of simulation time. The numbers of years were used as replicates, except in testing Hypothesis 2 (that under dryland maize cropping, nitrate leaching and maize grain yield from sludge-amended soils compared with inorganic fertilizer will not vary across seasons at a specific site), where the number of years was used as the main effect. Statistical analyses were done using general linear model (GLM) procedures of Windows SAS version 9.4 (SAS Institute, 2012).

\section{RESULTS AND DISCUSSION}

\section{Maize grain yield and nitrate leaching across South African agro-ecological zones and sites}

Model scenario simulation was carried out to predict maize grain yield and nitrate leaching from sludge-amended soils across 5 of the 6 South African agro-ecological zones. Findings from these model simulation results are presented in the following sections.

\section{Maize grain yield from sludge-amended soils and inorganic fertilizer}

Maize grain yield varied significantly across the 4 agroecological zones for both sludge and inorganic fertilizeramended soils (Fig. 1). Generally, maize yield was higher from sludge-amended soils than lands receiving inorganic fertilizer (Fig. 1). The highest average grain yield of $12.6 \mathrm{tha}^{-1}$ was predicted for the super-humid zone (Nelspruit) under sludge treatment, while lowest yield of $4.1 \mathrm{t} \cdot \mathrm{ha}^{-1}$ was recorded in the semi-arid zone of Bloemfontein under inorganic fertilizer application. Generally, the predicted yield for the sites was within the ranges reported by FSSA (2007). 
Table 5. Potential maize grain yield and annual inorganic nitrogen fertilizer and sludge application rate recommendations for selected sites across South African agro-ecological zones

\begin{tabular}{|c|c|c|c|c|c|}
\hline $\begin{array}{l}\text { Agro-ecological } \\
\text { zone }\end{array}$ & $\begin{array}{l}\text { Selected } \\
\text { sites }\end{array}$ & $\begin{array}{l}\text { Mean annual rainfall } \\
\qquad(\mathrm{mm})\end{array}$ & $\begin{array}{c}\text { Potential maize } \\
\text { yield } \\
\left(\mathrm{t} \cdot \mathrm{ha}^{-1}\right)^{1}\end{array}$ & $\begin{array}{c}\text { Inorganic N } \\
\text { fertilizer } \\
\left(\mathrm{kg} \cdot \mathrm{ha}^{-1}\right)^{1}\end{array}$ & $\begin{array}{c}\text { Sludge } \\
\text { recommendation } \\
\text { rate }\left(\mathrm{t} \cdot \mathrm{ha}^{-1}\right)^{2}\end{array}$ \\
\hline \multirow[t]{3}{*}{ Semi-arid } & Bloemfontein & 401 & 4.5 & 47 & 6.5 \\
\hline & Rustenburg & 475 & 6.5 & 72 & 8.7 \\
\hline & Polokwane & 391 & 6 & 66 & 7.7 \\
\hline \multirow[t]{3}{*}{ Sub-humid } & Johannesburg & 790 & $8-9$ & 120 & 13.8 \\
\hline & Port Alfred & 726 & $7-8$ & 90 & 10.3 \\
\hline & Bethlehem & 705 & $7-8$ & 90 & 10.3 \\
\hline \multirow[t]{3}{*}{ Humid } & Durban & 965 & $10-10.5$ & 150 & 13.5 \\
\hline & East London & 816 & $8-9$ & 130 & 11.7 \\
\hline & Cape Town & 831 & $8-9$ & 130 & 11.7 \\
\hline Super-humid & Nelspruit & 1003 & $11-12$ & 170 & 13.5 \\
\hline
\end{tabular}

${ }^{1}$ FSSA, 2007; ${ }^{2}$ Ogbazghi et al., 2015

The mean annual maize grain yield varied significantly $(P<0.05)$ between sites within an agro-ecological zone (Fig. 2). In the sub-humid zone, maize grain yield in Johannesburg was $20 \%$ higher under sludge-amended and $32 \%$ higher under inorganic fertilizer-amended soils than for Bethlehem. Similarly, in the semi-arid zone, maize grain yield in Rustenburg was $25 \%$ higher under sludge-amended and $20 \%$ higher under inorganic fertilizer-amended soils than in Bloemfontein. In the humid zone, maize grain yield in Durban was $20 \%$ higher under sludge-amended and $28 \%$ higher under inorganic fertilizer-amended soils than in East London (Fig. 2). These variations are attributed to the differences in rainfall and temperature between sites, which affected dry matter production and grain yield.

It was apparent from the simulations that maize grain yield from sludge-amended soils varied significantly $(P<0.05)$ across agro-ecological zones and sites compared with inorganic fertilizer. Maize grain yield was higher from sludge-amended soils than inorganic fertilizer, indicating the agronomic benefits of sewage sludge over inorganic fertilizer.

\section{Nitrate leaching from sludge-amended soils and inorganic fertilizer}

Henceforth, the simulation findings showed that nitrate leaching varied significantly $(P<0.05)$ across agro-ecological zones for both inorganic fertilizer and sludge-amended soils (Fig. 3). Cumulative annual nitrate leaching varied from $11.2 \mathrm{kgNO}_{3}-\mathrm{N} \cdot \mathrm{ha}^{-1}$ (semi-arid) to $43.2 \mathrm{kgNO}_{3}-\mathrm{N} \cdot \mathrm{ha}^{-1}$ (superhumid) for inorganic fertilizer-amended soils and from $5.6 \mathrm{kgNO}_{3}-\mathrm{N} \cdot \mathrm{ha}^{-1}$ (semi-arid) to $32.7 \mathrm{kgNO}_{3}-\mathrm{N} \cdot \mathrm{ha}^{-1}$ (superhumid) for sludge-amended soils. Generally, nitrate leaching within each agro-ecological zone was significantly higher $(P<0.05)$ from inorganic fertilizer-amended soils than sludge-amended soils (Fig. 3).

Simulations also showed that nitrate leaching varied between sites within an agro-ecological zone (Fig. 4). For instance, in the semi-arid zone, leaching was higher in Rustenburg $\left(8.1 \mathrm{kgNO}_{3}-\mathrm{N} \cdot \mathrm{ha}^{-1}\right)$ than in Bloemfontein $\left(4.1 \mathrm{kgNO}_{3}-\mathrm{N} \cdot \mathrm{ha}^{-1}\right)$ and Polokwane $\left(5.6 \mathrm{kgNO}_{3}-\mathrm{N} \cdot \mathrm{ha}^{-1}\right)$; in the sub-humid zone, leaching was higher in Johannesburg $\left(34.2 \mathrm{kgNO}_{3}-\mathrm{N} \cdot \mathrm{ha}^{-1}\right)$ than in Bethlehem $\left(14.2 \mathrm{~kg} \mathrm{NO}_{3}-\mathrm{N} \mathrm{ha}^{-1}\right)$ and Port Alfred $\left(8.3 \mathrm{kgNO}_{3}-\mathrm{N} \cdot \mathrm{ha}^{-1}\right)$; and in the humid zone, leaching was higher in Durban $\left(40.2 \mathrm{kgNO}_{3}-\mathrm{N} \cdot \mathrm{ha}^{-1}\right)$ than in East London (13.2 $\left.\mathrm{kgNO}_{3}-\mathrm{N} \cdot \mathrm{ha}^{-1}\right)$ (Fig. 4).
The variation in nitrate leaching between agro-ecological zones generally follows a similar pattern to the rainfall for both inorganic fertilizer and sludge-amended soils. This concurs with previous findings that reported a direct relationship between water availability and nitrate leaching (Tesfamariam et al., 2015; Holland et al., 2018). Similarly, the difference in nitrate leaching between sites within an agroecological zone was attributed mainly to the variation in rainfall amount and distribution. For instance, in the semiarid zone annual rainfall was $75 \mathrm{~mm}$ higher in Rustenburg than Bloemfontein; in the sub-humid zone, rainfall was 80 $\mathrm{mm}$ and $60 \mathrm{~mm}$ higher in Johannesburg than Bethlehem and Port Alfred; and in the humid zone, rainfall was $150 \mathrm{~mm}$ and $134 \mathrm{~mm}$ higher in Durban than East London and Cape Town (Tables 5 and 6).

This significant variation between sludge application and inorganic fertilizer was attributed mainly to the form of N. A large fraction of the $\mathrm{N}$ in sludge $(>70 \%)$ is organic, which is released gradually to plant-available form. In contrast, $\mathrm{N}$ in inorganic fertilizers is all inorganic and is potentially leachable under excessive rainfall.

Nitrate losses are low from sludge-amended soils compared with the conventional agronomic use of inorganic fertilizer. For instance, in the semi-arid zone of Rustenburg, only $2.3 \%$ of the organic $\mathrm{N}$ that is added with sludge was leached, compared with $11.1 \%$ for inorganic fertilizer. Similarly, in the sub-humid zone in Johannesburg, $6.2 \%$ of the organic $\mathrm{N}$ was leached from sludge compared with $28.5 \%$. In the humid zone of Durban $7.9 \%$ of the organic $\mathrm{N}$ was leached from sludge compared with $26.7 \%$. In the super-humid zone of Nelspruit, only $8.2 \%$ of the organic $\mathrm{N}$ that is added with sludge was leached as nitrate, compared with $25.4 \%$ of inorganic fertilizer. Therefore, using sludge in agricultural lands has a low risk of nitrate leaching compared with inorganic fertilizer. Therefore, the hypothesis that 'under dryland maize cropping, annual maize grain yield and nitrate leaching from sludge-amended soils will remain the same as inorganic fertilizer-amended soil across agroecological zones and sites' is not accepted.

\section{Nitrate leaching and maize yield across seasons}

Model scenario simulation was carried out to predict maize grain yield and nitrate leaching from sludge-amended soils across seasons within a site. Findings from these model simulation results are presented in the following sections. 


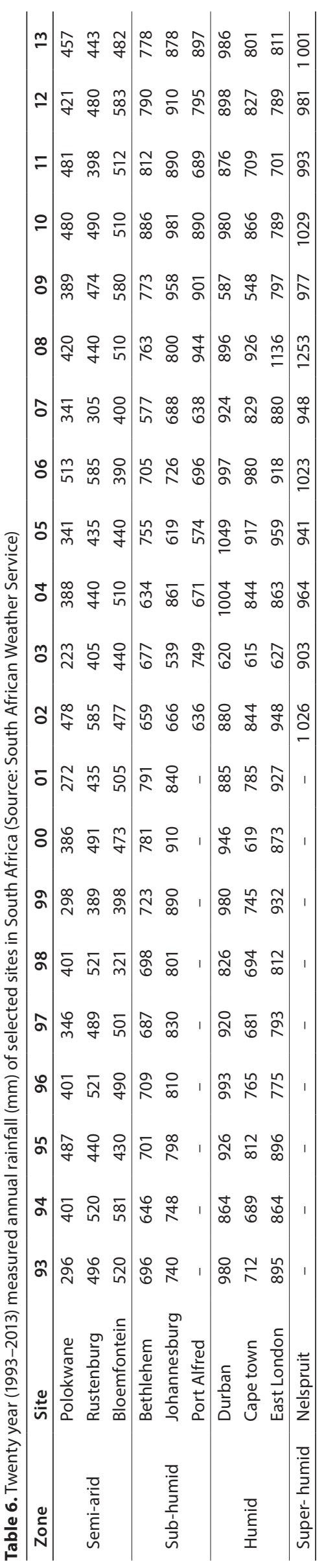

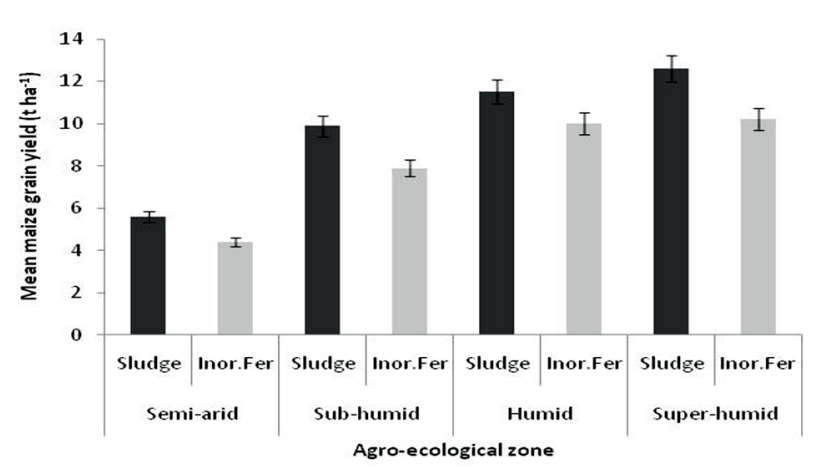

Figure 1. Model scenario simulations of maize grain yield from sludge-amended soils compared with inorganic fertilizer across agro-ecological zones in South Africa. Values presented are means of the values over 20 years. Error bars represent standard error with $5 \%$ value. Inor.Fer is inorganic fertilizer.

\section{Maize grain yield over years within a site}

Model simulations were conducted for over 20 years on 2 selected sites, namely, Johannesburg (sub-humid zone) and Durban (humid zone), to assess maize grain yield from sludge and inorganic fertilizer-amended soils. Maize grain yield varied significantly over years, both for inorganic fertilizer and sludge-treated soils (Fig. 5). Generally, maize grain yield was higher for soils fertilized with sludge than inorganic fertilizer in both Johannesburg and Durban. For instance, in the subhumid zone of Johannesburg, maize grain yield from sludgeamended soil was predicted to be $10-15 \%$ higher than soils amended with inorganic fertilizer (Fig. 5a). Similarly, in the humid zone of Durban, maize grain yield was $15-20 \%$ higher in sludge-amended soils than those fertilized with inorganic fertilizer over 20 years (Fig. 5b).

The difference in maize grain yield between years was statistically significant $(P<0.05)$ when the difference in rain amount between years exceeded $241 \mathrm{~mm}$ (semi-arid zone), $362 \mathrm{~mm}$ (sub-humid zone), and $429 \mathrm{~mm}$ (humid zone). This event happened in 2 of the 20 years (2002 and 2004) of model simulation for both Johannesburg and Durban. Nitrate leaching in these 2 years was also lower compared with other years (Fig. 6). The low rainfall events of 2002 and 2004 led to low grain yield and nitrate leaching, because there is a direct relationship between water availability and maize grain yield (Nilahyane et al., 2019) as well as between high rainfall events and nitrate leaching (Holland et al., 2018). It is well documented that the presence of water plays a critical role in both nutrient uptake by plants and release of nutrients as plant-available inorganic forms from organic nutrient sources (Guntiňas et al., 2012, Ogbazghi et al., 2015).

\section{Nitrate leaching over years within a site}

Nitrate leaching varied significantly $(P<0.05)$ over the years under both sludge and inorganic fertilizer-amended soils (Fig. 6a and 6b). Nitrate leaching remained significantly higher under inorganic fertilizer-amended soils than those that received sludge. For instance, in the sub-humid zone of Johannesburg, the mean annual nitrate leaching from inorganic fertilizer was $15 \%$ higher than with sludge-treated soils (Fig. 6a). Similarly, in the humid zone of Durban, the mean annual nitrate leaching from inorganic fertilizer-treated soil was $20 \%$ higher than for sludge-treated soil (Fig. 6 b). Similar to 


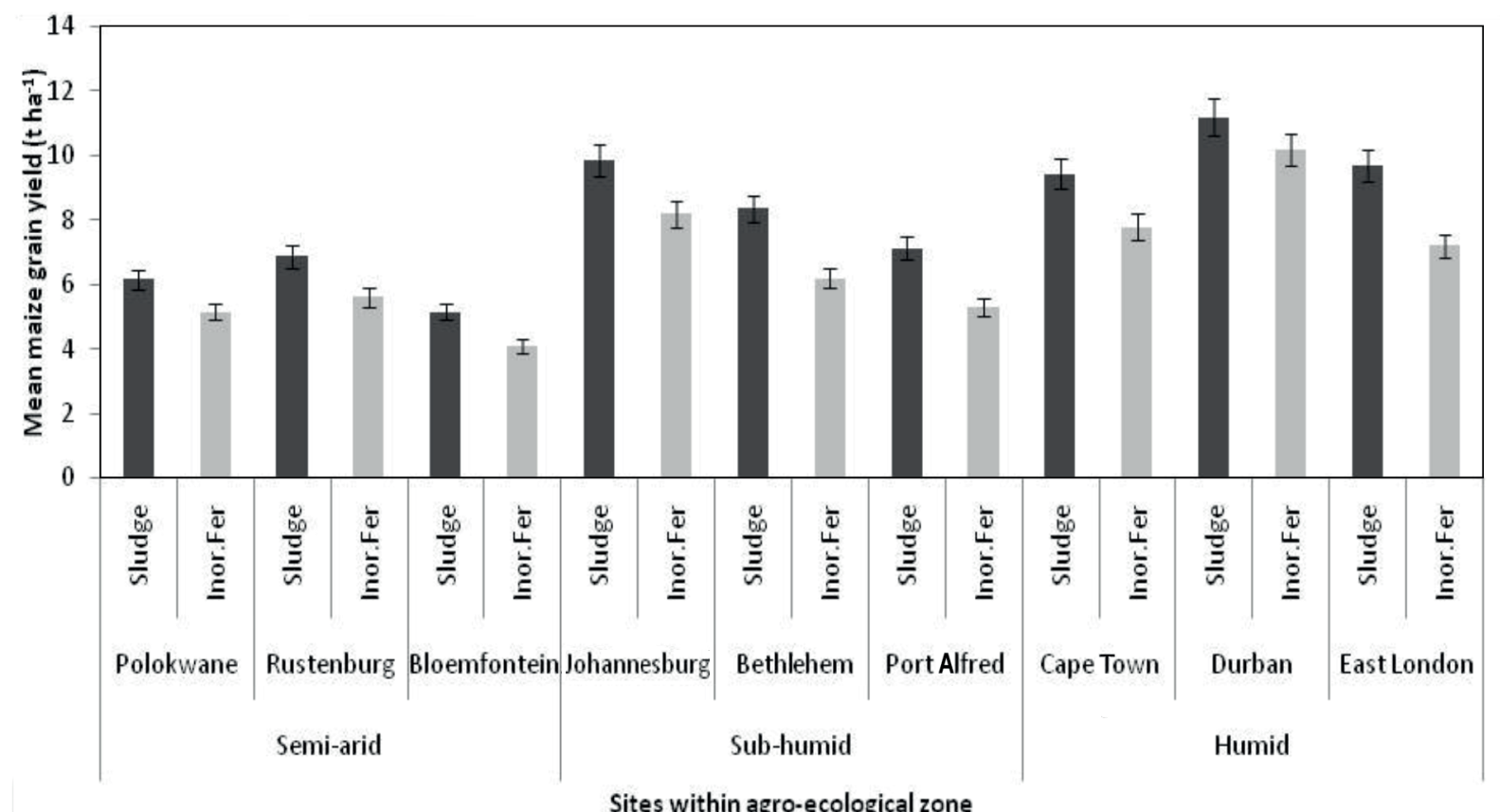

Sites within agro-ecological zone

Figure 2. Model scenario simulations of maize grain yield from sludge-amended soils compared with inorganic fertilizer within selected sites in South African agro-ecological zone. Values presented are means of the values over 20 years. Error bars represent standard error with $5 \%$ value. Inor.Fer is inorganic fertilizer.

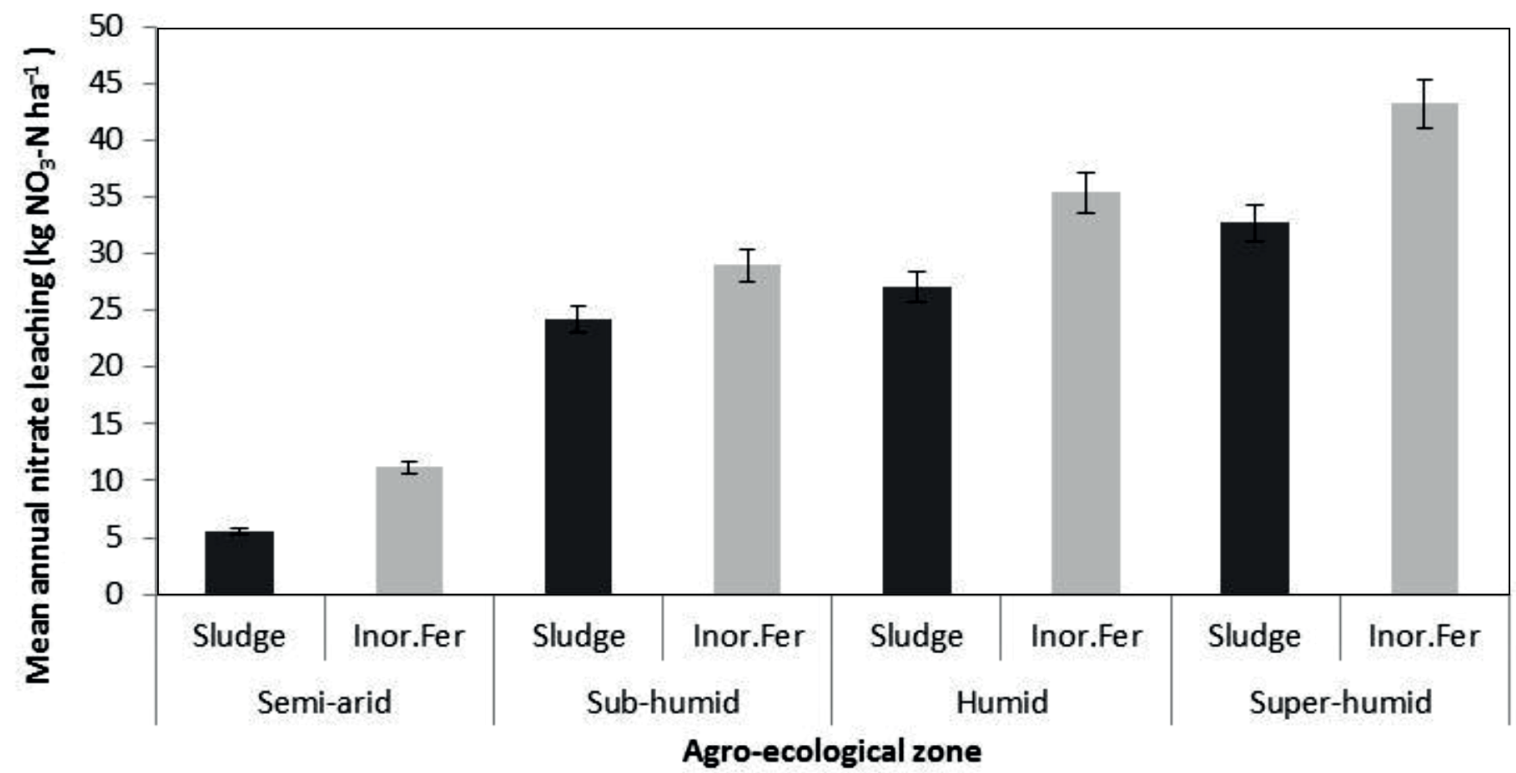

Figure 3. Model scenario simulations of nitrate leaching from sludge-amended soils compared with inorganic fertilizer across agro-ecological zones. Values presented are means of the values over 20 years. Error bars represent standard error with 5\% value. Inor.Fer is inorganic fertilizer.

maize grain yield, the significant difference $(P<0.05)$ in nitrate leaching between years was observed in 2 of the 20 years.

The observed increase in nitrate leaching as the rainfall increased is attributed to the increase in the mobility of nitrate within the profile, at a relatively faster rate than the rate of uptake by plants. Such interactive effects of both rainfall and leaching on uptake of $\mathrm{N}$ by plants are well documented (Banger et al., 2018). Holland et al. (2018) and Ogbazghi et al. (2016) reported a direct relationship between nitrate leaching and soil water availability. Therefore, the hypothesis that 'under dryland maize cropping, annual maize grain yield and nitrate leaching will not vary across years both from sludge and inorganic fertilizer-amended soils' is not accepted.

\section{Maize grain yield and nitrate leaching across soil textures}

Maize grain yield and nitrate leaching varied significantly $(P<0.05)$ between soil textures for both sludge and inorganic fertilizer-amended soils (Fig. 7a and 7b). Maize grain yield was 


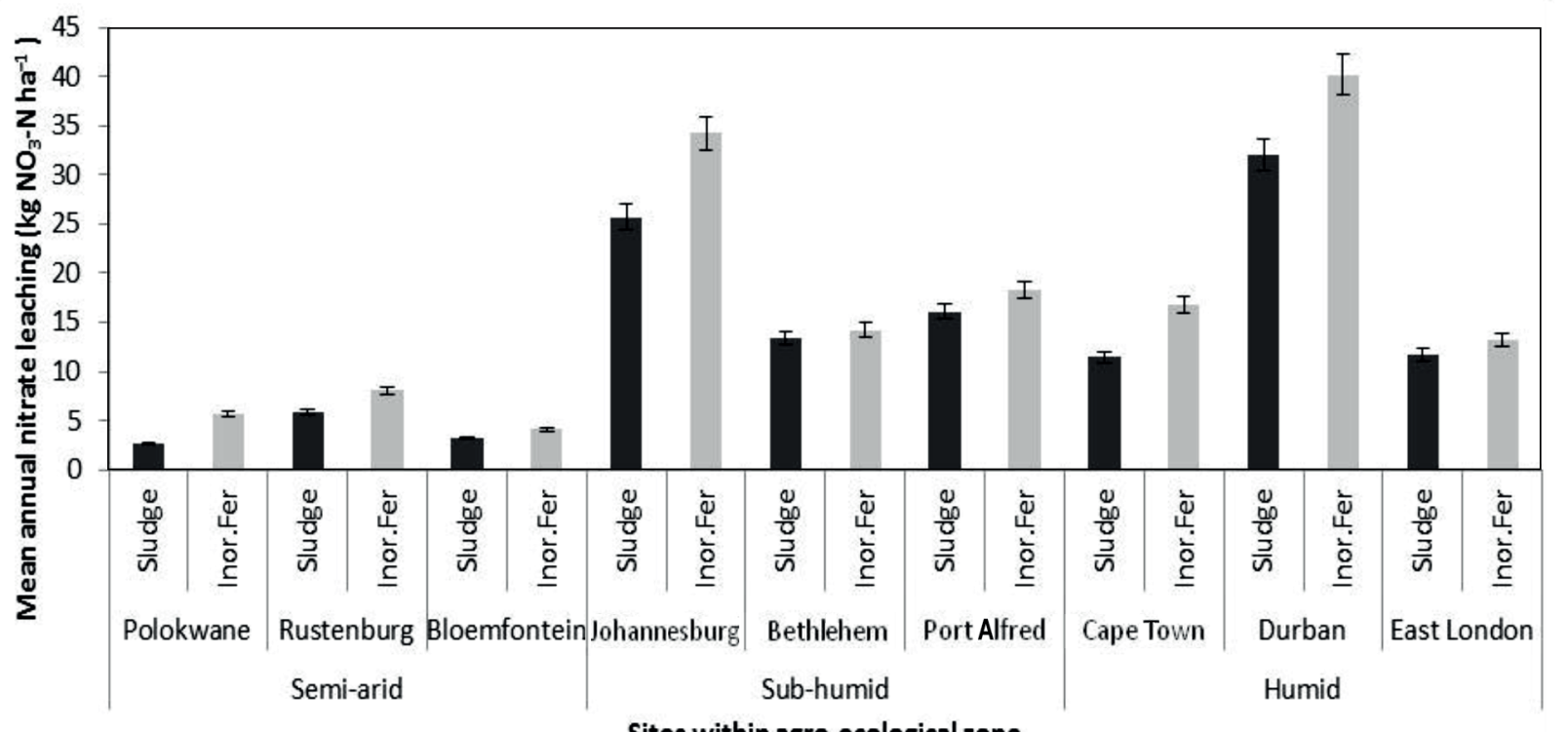

Sites within agro-ecological zone

Figure 4. Model scenario simulations of nitrate leaching from sludge-amended soils compared with inorganic fertilizer within selected sites in South African agro-ecological zones. Values presented are means of the values over 20 years. Error bars represent standard error with $5 \%$ value. Inor.Fer is inorganic fertilizer.
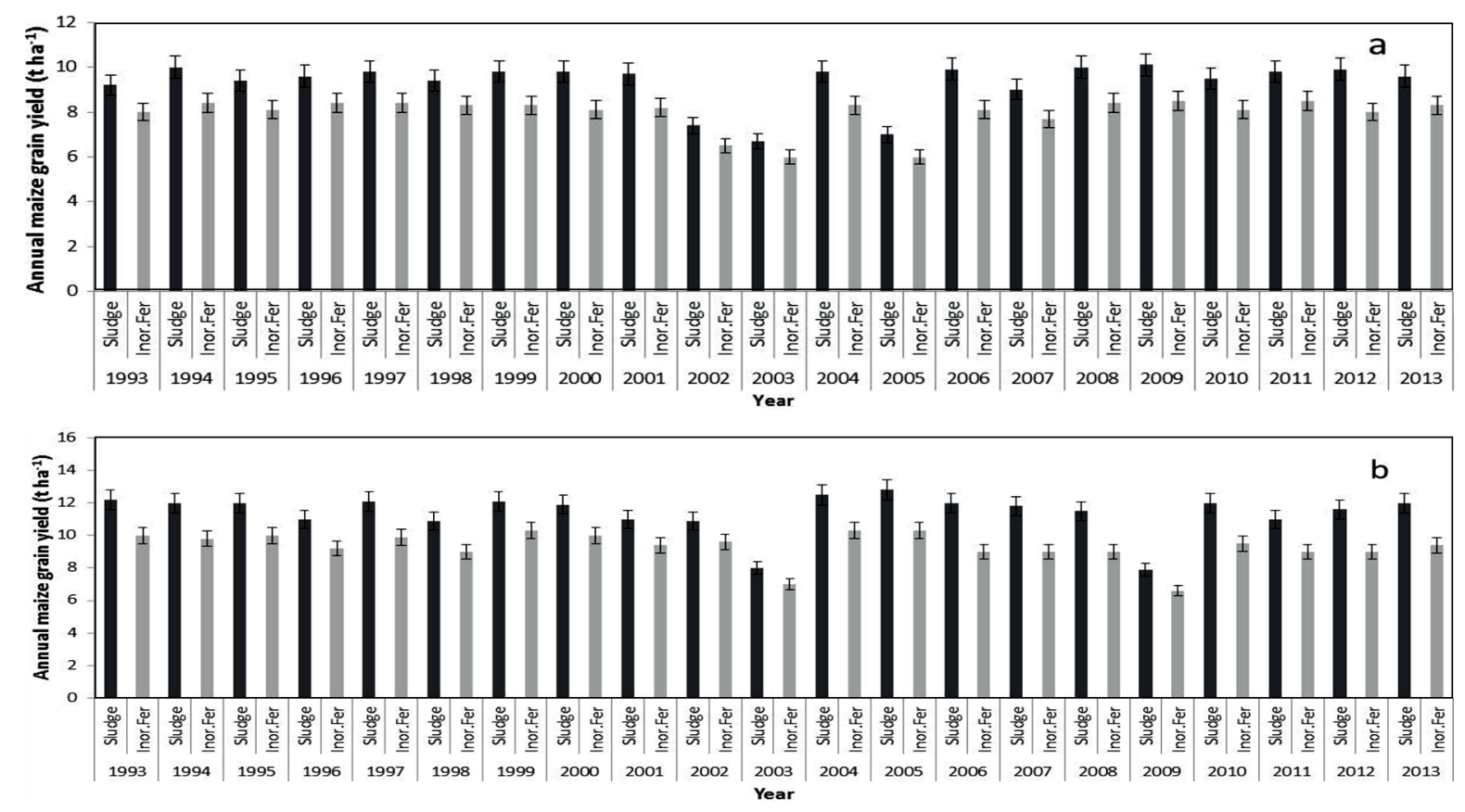

Figure 5. Model predictions of maize grain yield from sludge-amended and inorganic fertilizer applied to meet the crop $\mathrm{N}$ requirement in the (a) sub-humid zone of Johannesburg and (b) humid zone of Durban over 20 years of simulations. Values presented are means of the maize grain yield from clay, clay loam, sandy clay loam and sandy loam soils. Error bars represent standard error with $5 \%$ value. Inor.Fer is inorganic fertilizer.

predicted to be higher for clay loam and sandy clay loam soils than for clay and sandy loam soils (Fig. 7a). It was also apparent that maize grain yield was higher from sludge-amended than inorganic fertilizer-amended soil across soil textures (Fig. 7a). This is mainly due to the higher nitrate leaching from inorganic fertilizer compared with sludge-amended soil (Fig. 7b).

Nitrate leaching from inorganic fertilizer-amended soils was generally higher than from sludge-amended soils (Fig. 7b).
Nitrate leaching was lower in clay and clay loam soils than in sandy clay loam and sandy loam soils in both sludge and inorganic fertiliser soils. This agrees with the general literature in which nitrate leaching from sand-dominated soils is reported to be higher (Elasbah et al., 2019; Fang and Su, 2019). Therefore, the hypothesis that 'under dryland maize cropping, annual maize grain yield and nitrate leaching will remain similar across soil textures' is not accepted. 

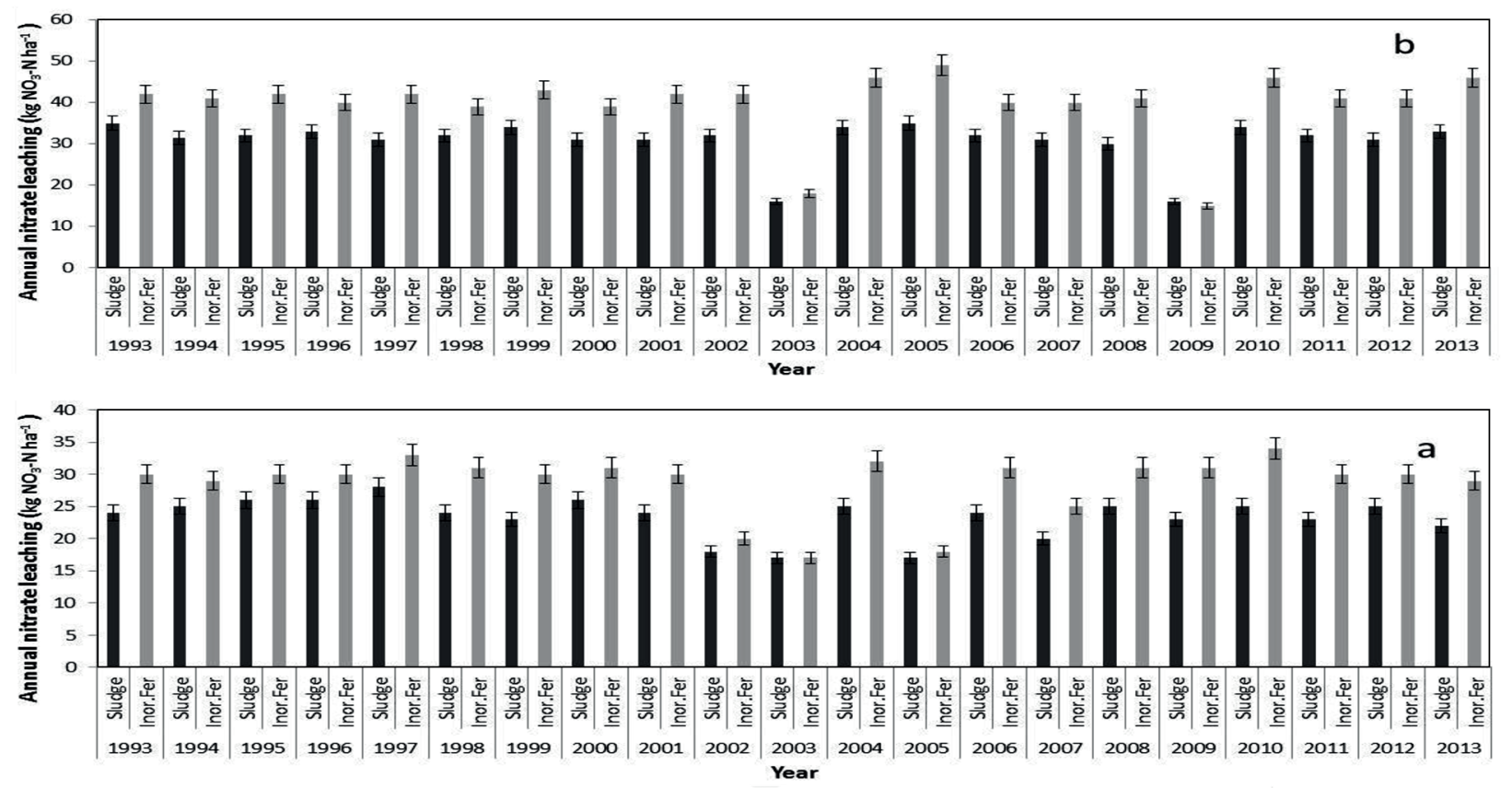

Figure 6. Model predictions of nitrate from sludge-amended soils and inorganic fertilizer applied to meet crop $\mathrm{N}$ requirement in the (a) subhumid zone of Johannesburg and (b) humid zone of Durban over 20 years of simulations. Values presented are means of the nitrate leaching from clay, clay loam, sandy clay loam and sandy loam soils. Error bars represent standard error with $5 \%$ value. Inor.Fer is inorganic fertilizer.
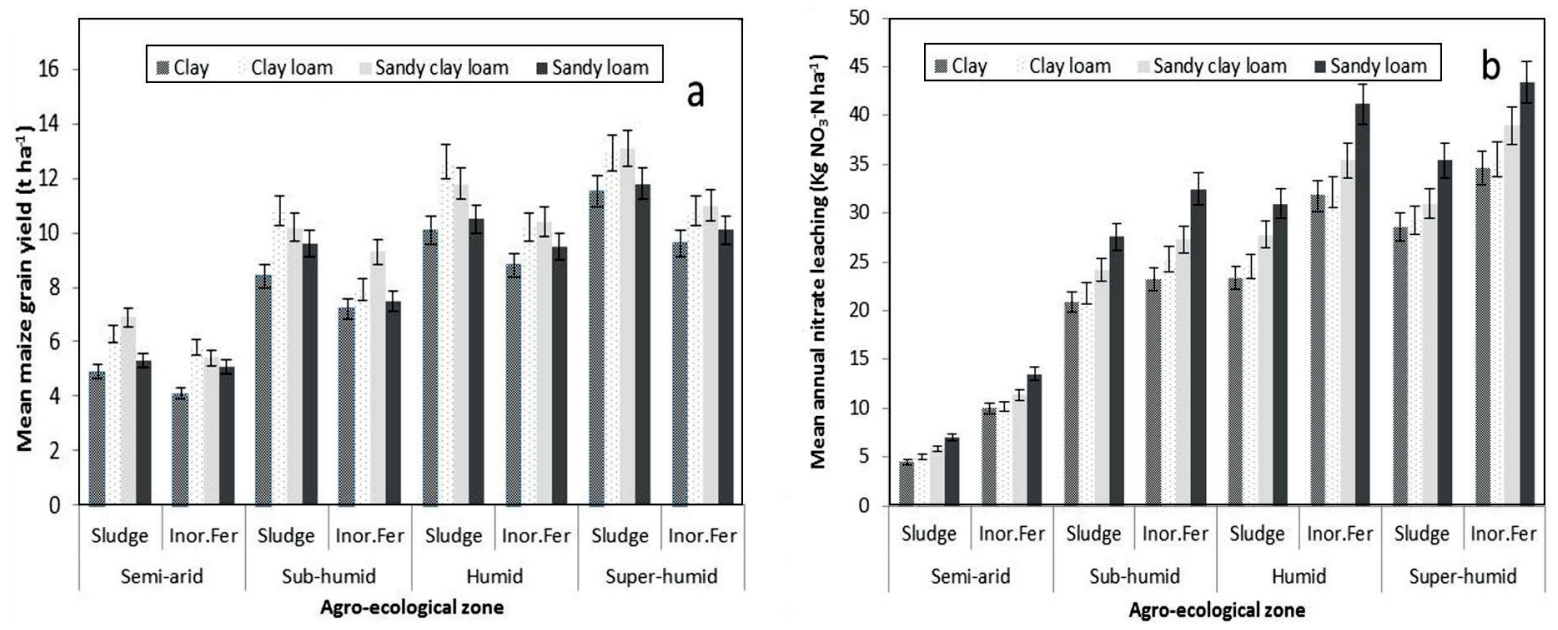

Figure 7. Model scenario simulations of (a) maize grain yield and (b) nitrate leaching from sludge-amended soils compared with inorganic fertilizer across South African agro-ecological zones as affected by soil texture. Values presented are means of the values over 20 years. Error bars represent standard error with $5 \%$ value. Inor.Fer is inorganic fertilizer.

\section{CONCLUSIONS}

Predicted maize grain yield and nitrate leaching varied significantly across 4 agro-ecological zones, for both sludgeamended and inorganic fertilizer-amended soils. Similarly, maize grain yield and nitrate leaching, were predicted to vary significantly across seasons and soil textures for both the sludge- and inorganic fertilizer-amended soils. However, nitrate leaching losses were lower from sludgeamended soils compared with those receiving inorganic fertilizer across all agro-ecological zones. Predicted maize grain yield was higher from sludge-amended soils than for inorganically fertilized crops, while nitrate leaching was higher with inorganic fertilizer than with sludge, indicating the agronomic and environmental benefits of municipal sludge over inorganic fertilizer. Further validation of these findings using field experiments and monitoring potential $\mathrm{P}$ accumulation for soils that received sludge according to crop $\mathrm{N}$ requirements is recommended.

\section{ACKNOWLEDGMENTS}

The authors would like to express their appreciation and gratitude to the Water Research Commission of South Africa (WRC) and East Rand Water Care Works (ERWAT) for the funding without which this study would have been but a dream. 
The authors would like to further express their gratitude to the Agro-Climatology Unit of the South African Agricultural Research Council - Soil, Climate, and Water for providing us with the long-term weather data for the study sites.

\section{REFERENCES}

ALVAREZ-CAMPOS OM (2019) Assessment of exceptional quality biosolids for urban agriculture. PhD dissertation, Virginia Polytechnic Institute and State University, USA. 145-183.

ANNANDALE JG, CAMPBELL GS, OLIVIER FC and JOVANOVIC NZ (2000) Predicting crop water uptake under full and deficit irrigation: An example using pea (Pisum sativum L. cv. Puget). Irrig. Sci. 19 65-72. https://doi.org/10.1007/s002710050002

ANNANDALE J, JOVANOVIC N, CAMPBELL G, SAUTOY ND and BENADE N (2003) A two-dimensional water balance model for micro-irrigated hedgerow tree crops. Irrig. Sci. 22 157-170. https:// doi.org/10.1007/s00271-003-0081-7

BANGER K, NAFZIGER ED, WAND J, MUHAMMAD U and PITTELKOW CM (2018) Simulating nitrogen management impacts on maize production in the U.S. Midwest. PloS ONE 13 10. https:// doi.org/10.1371/journal.pone.0201825

BANGER K, YUAN M, WANG J, NAFZIGER ED and PITTELKOW CM (2017) A vision for incorporating environmental effects into nitrogen management decision support tools for U.S. maize production. Front. Plant Sci. 8 1270. https://doi.org/10.3389/ fpls.2017.01270

BOUNIOLS A, CABELGUENNE M, JONES CA, CHALAMET A, CHARPENTEAU JL and MARTY JR (1991) Simulation of soybean nitrogen nutrition for a silty clay soil in southern France. Field Crops Res. 26 19-34. https://doi.org/10.1016/0378-4290(91)90054-Y

BRADY NC (1974) The Nature and Property of Soils ( $8^{\text {th }}$ edn). Macmillan Publishing Company, Inc., New York, N.Y.

DU PLESSIS (2003) Maize production. Department of Agriculture, ARC-Grains Crop institute, RSA, URL: www.nda.agric.za/ publications.

ELASBAH R, SELIM T, MIRDAN A, and BERNDTSSON R (2019) Modelling of fertilizer transport for various fertigation scenarios under drip irrigation. Water 11 893. https://doi.org/10.3390/ w11050893

FANG J and SU Y (2019) Effects of soils and irrigation volume on maize yield, irrigation water productivity, and nitrogen uptake. Sci. Rep-UK 97740 . https://doi.org/10.1038/s41598-019-41447-z

FAO (2005) Fertilizer use by crop in South Africa. FAO, Rome, Italy.

FSSA (2007) Fertilizer Handbook (6 ${ }^{\text {th }}$ edn). The Fertilizer Society of South Africa. Beria Printers, South Africa. 99-123.

GODWIN DC and JONES CA (1991) Nitrogen Dynamics in the SoilPlant Systems. 289-321.

GUNTIŇAS ME, LEIROS MC, TRASAR-CEPEDA C and GILSOTRES F (2012) Effects of moisture and temperature on net soil nitrogen mineralization: A laboratory study. Eur. J. Soil Biol. 48 73-80. https://doi.org/10.1016/j.ejsobi.2011.07.015

HASSINK J, SCOLEFLED D and BLANTERN P (1990) Nitrogen mineralization in grassland soil. In: Gaborcik N, Krajcovic V and Zimkova M (eds). Proc. $13^{\text {th }} \mathrm{Gen}$. Meeting of the Eur. Grassland Federation, Banscka Bystrica, Tsjechoslovakia, vol II. 25-32.

HOLLAND JE, BENNETT AE, NEWTON AC, WHITE PJ, MCKENZIE BM, GEORGE TS, PAKEMAN RJ, BAILEY JS, FORNAR DA and HAYES RC (2018) Liming impacts on soils, crops and biodiversity in the UK: A review. Sci. Total Environ. 610-611 316-332. https://doi.org/10.1016/j.scitotenv.2017.08.020

KAIKCIOGLU HH and DELIBACAK S (2018) Changes in soil health and crop yield in response to the short-term application of sewage sludge to typic xerofluvent soil in Turkey. Appl. Ecol. Environ. Res. 16 4893-4917. https://doi.org/10.15666/aeer/1604_48934917
LADD JN, AMATO M, JOCTEUR-MONROZIER L and VAN GESTEL M (1990) Soil microhabitats and carbon and nitrogen metabolism. In: Proc. $14^{\text {th }}$ Int. Congress Soil Sci., Kyoto, Japan, Vol III. 82-87.

MALOBANE ME (2014) Using the organic carbon fractions of the Van Soest method to determine compounds responsible for $\mathrm{C}$ and $\mathrm{N}$ mineralization from sludge amended soils. MSc. dissertation, University of Pretoria, South Africa. 56-64.

MILES N and MANSON AD (2000) Nutrition of planted pastures. In: Tainton NM (ed.). Pasture Management in South Africa. University of Natal Press, Pietermaritzburg.

NILAHYANE A, ISLAM MA, MESBAH AO and GARCIA AG (2019) Effect of irrigation and nitrogen fertilization strategies on silage corn grown in semi-arid conditions. Agron 8 208. https://doi. org/10.3390/agronomy8100208

OGBAZGHI ZM, TESFAMARIAM EH and ANNANDALE JG (2016) Modelling $\mathrm{N}$ mineralisation from sludge-amended soils across agro-ecological zones: A case study from South Africa. J. Ecol. Model. 322 19-30. https://doi.org/10.1016/j.ecolmodel.2015.11.019

PARAMASHIVAM D, DICKINSON NM, CLOUGH TJ, HORSWELL J and ROBINSON BH (2017) Potential environmental benefits from blending biosolids with other organic amendments before application to land. J. Environ. Qual. 43 481-489. https://doi. org/10.2134/jeq2016.10.0421

RHOADS FM and BENNETT JM (1990) Corn. In: Stewart BA and Nielsen DR (ed.). Irrigation of Agricultural Crops. American Society of Agronomy, Madison, Wis.

SAS INSTITUTE INC (2012) The SAS system for Windows, Version 9.4., SAS Institute Inc., Cary, NC, USA.

SCHOEMAN JL and VAN DER WALT M (2004) Agricultural Research Council - Institute for Soil, Climate and Water. Overview of the status of the agricultural natural resources of South Africa. Report No. GW/A/2004/13. ARC-ISCW, Pretoria. 106-118.

SOIL CLASSIFICATION WORKING GROUP (1991) Soil classification: A taxonomic system for South Africa. Dep. of Agric. Development, Pretoria, South Africa.

STÖCKLE CO and CAMPBELL GS (1989) Simulation of crop response to water and nitrogen: an example using spring wheat. Trans. ASAE 32 66-68. https://doi.org/10.13031/2013.30964

STÖCKLE CO, DONATELLI M and NELSON R (2003) CropSyst, a cropping systems simulation model. Eur. J. Agron. 18 289-307. https://doi.org/10.1016/S1161-0301(02)00109-0

STÖCKLE CO, MARTIN SA and CAMPBELL GS (1994) CropSyst, a cropping systems model: Water/nitrogen budgets and crop yield. Agric. Syst. 46 335-359. https://doi org/10.1016/0308-521X(94)90006-2

TESFAMARIAM EH (2009) Sustainable use of sewage sludge as a source of nitrogen and phosphorus in cropping systems. PhD thesis, University of Pretoria, South Africa, pp. 153-159.

TESFAMARIAM EH, ANNANDALE JG, STEYN JM, STIRZAKER RJ and MBAKWE I (2015) Use of the SWB-Sci model for nitrogen management in sludge-amended land. Agric. Water Manage. 152 262-276. https://doi.org/10.1016/j.agwat.2015.01.023

TISDALE SL, NELSON WL and BEATON ID (1985) Soil fertility and Fertilizers ( $4^{\text {th }}$ edn). Macmillan Publishing Company, New York.

USEPA (2012) A Plain English Guide to the EPA Part 503 Biosolids Rule. USEPA Rep. 93/003-832. U.S. Gov. Print. Office, Washington, D.C.

VAN DER LAAN M, STIRZAKER RJ, ANNANDALE JG, BRISTOW KL and DU PREEZ CC (2010) Monitoring and modelling draining and resident soil water nitrate concentrations to estimate leaching losses. Agric. Water Manage. 97 1779-1786. https://doi. org/10.1016/j.agwat.2010.06.012

VERBERNE ELJ, HASSINK J, DE WILLIGEN P, GROOT JJR and VAN VEEN JA (1990) Modelling organic matter dynamics in different soils. Neth. J. Agric. Sci. 38 221-238.

ZHAO H, LI X, and JIANG Y (2019) Response of nitrogen losses to excessive nitrogen fertilizer application in intensive greenhouse vegetable production. Sustainability 11 1513. https://doi. org $/ 10.3390 /$ su11061513 